\title{
OPTIMAL RETIREMENT ASSET DECUMULATION STRATEGIES: THE IMPACT OF HOUSING WEALTH
}

\author{
Wei Sun, Robert K. Triest, and Anthony Webb* \\ CRR WP 2006-22 \\ Released: November 2006 \\ Draft Submitted: October 2006 \\ Center for Retirement Research at Boston College \\ 258 Hammond Street \\ Chestnut Hill, MA 02467 \\ Tel: 617-552-1762 Fax: 617-552-0191 \\ http://www.bc.edu/crr
}

\begin{abstract}
*Wei Sun is a graduate research assistant at the CRR. Robert K. Triest is a visiting scholar at the CRR. Anthony Webb is a research economist at the Center for Retirement Research at Boston College (CRR). The research reported herein was performed pursuant to a grant from the U.S. Social Security Administration (SSA) funded as part of the Retirement Research Consortium. The findings and conclusions are solely those of the authors and do not represent the views of SSA, any agency of the Federal Government or Boston College.

(C) 2006, by Wei Sun, Robert Triest, and Anthony Webb. All rights reserved. Short sections of text, not to exceed two paragraphs, may be quoted without explicit permission provided that full credit, including $\odot$ notice, is given to the source. The authors would like to thank George Downey for helpful advice.
\end{abstract}




\section{About the Center for Retirement Research}

The Center for Retirement Research at Boston College, part of a consortium that includes parallel centers at the University of Michigan and the National Bureau of Economic Research, was established in 1998 through a grant from the Social Security Administration. The goals of the Center are to promote research on retirement issues, to transmit new findings to the policy community and the public, to help train new scholars, and to broaden access to valuable data sources. Through these initiatives, the Center hopes to forge a strong link between the academic and policy communities around an issue of critical importance to the nation's future.

\section{Center for Retirement Research at Boston College}

258 Hammond Street

Chestnut Hill, MA 02467

phone: 617- 552- 1762 fax: 617- 552- 0191

e-mail: crr@bc.edu

www.bc.edu/crr

Affiliated Institutions:

American Enterprise Institute

The Brookings Institution

Center for Strategic and International Studies

Massachusetts Institute of Technology

Syracuse University

Urban Institute 


\begin{abstract}
A considerable literature examines the optimal decumulation of financial wealth in retirement. We extend this line of research to incorporate housing, which comprises the majority of most households' non-pension wealth.

We use VARs to estimate the relationship among the returns on housing, stocks, and bonds, and use simulation techniques to investigate a variety of decumulation strategies incorporating reverse mortgages. Under a wide variety of assumptions, we find that the average household would be as much as 33 percent better off taking a reverse mortgage as a lifetime income relative to what appears to be the most common strategy of delaying until financial wealth is exhausted and then taking a line of credit. It would be as much as 62 percent better off relative to not taking a reverse mortgage at all. Housing wealth displaces bonds in optimal portfolios, making the low rate of participation in the stock market even more of a puzzle.
\end{abstract}




\section{Introduction}

Reverse mortgages enable households to consume part of their housing wealth in retirement while continuing to live in the house. In contrast to a conventional forward mortgage that requires regular payments of interest, the loan plus accumulated interest is only repayable when neither borrower lives in the house. The amount repayable is capped at the sale proceeds. Home Equity Conversion Mortgages, the product with over 90 percent of the market, allows borrowers to take their reverse mortgage in the form of a lump sum, a lifetime income, or a line of credit. ${ }^{1}$ As shown by Figure One, take-up of HECMs has grown rapidly, albeit from a very low base, rising from 8,127 in 2001 to 48,493 in $2005 .^{2}$ This paper investigates three related issues; what is the optimal age to take a reverse mortgage, in what form should it be taken, and what effect does their availability have on the optimal allocation of financial wealth.

We model this as both a portfolio allocation and a consumption decision. In addition to holding stocks and bonds, the household also owns a house. But it can't simply sell the house and consume the proceeds because it needs somewhere to live. But it can, through the mechanism of a reverse mortgage, "sell" the present value of the eventual sale proceeds - the reversionary interest - either immediately on retirement or, if it is not liquidity constrained, at a later date. ${ }^{3}$ The optimal strategy will depend on the expected returns to stocks, bonds, and the reversionary interest, the variances and covariances of those returns, and the household's attitude towards risk. It may also be affected by liquidity constraints.

Using a reduced form vector autoregression (VAR), we quantify the relationship among the returns to stocks, bonds, and an investment in the reversionary interest over the period 1975 to 2005 . We show that the capital return to housing, as measured by the Office of Federal Housing Enterprise and Oversight (OFHEO) house price index was quite modest and exhibited only small fluctuations - the mean and standard deviation were only 1.9 and 3.7 percent respectively. In contrast, an investment in the reversionary

\footnotetext{
1 www.nrmlaonline.org "About the HECM."

2 www.nrmlaonline.org"Annual Origination Volume for Home Equity Conversion Mortgages" to 30 September each year reported by U.S. Department of Housing and Urban Development.

${ }^{3}$ This is not strictly correct, as a household taking a reverse mortgage or its heirs is entitled to any excess of the sale proceeds over the loan plus accumulated interest.
} 
interest provided a much higher return, but at very high risk. For households aged 65, the mean and standard deviation of the real return to an investment in the reversionary interest amounted to 16.0 and 40.6 percent respectively. At high interest rates, interest will accrue more rapidly, and the maximum loan to valuation ratio is therefore inversely related to interest rates. In fact, the amount that can be borrowed on a reverse mortgage varies dramatically with even quite small changes in interest rates. The much greater standard deviation of the return to an investment in the reversionary interest is simply the result of movements in interest rates. The return is so much higher than the capital return to housing, partly because the percentage of the house that can be borrowed on a reverse mortgage increases with age, but mainly because interest rates fell during the period, resulting in dramatic increases in the proportion of the value of the house that could be borrowed.

We then simulate asset return histories based on our VAR, and use these histories to run Monte-Carlo simulations of the returns to alternative strategies for decumulating retirement wealth, inclusive of the reversionary interest, relative to a default of taking a reverse mortgage at age 65 and investing the proceeds in financial assets. We calculate the expected utility of each strategy, and then calculate reverse mortgage equivalent wealth, the factor by which the wealth of a household compelled to adopt the default strategy must be multiplied so that its expected utility equals that provided by the alternative. When reverse mortgage equivalent wealth exceeds 1.00 , the household would be better off choosing the alternative. We test the sensitivity of our results to alternative assumptions about the means and variances of the returns on the various asset classes.

We find that over a wide variety of assumptions about asset returns, the optimal strategy for all but the most risk tolerant households is to take a reverse mortgage in the form of a lifetime income. We are informed by the National Reverse Mortgage Lenders Association that only a small minority of borrowers choose this option, as most choose a line of credit. Our findings appear to be yet another manifestation of the widely documented reluctance of households to annuitize their wealth in retirement. There are substantial differences in reverse mortgage equivalent wealth among strategies, and in our base case a household with average housing and financial wealth and a coefficient of 
risk aversion of five would be 33 percent better off taking a lifetime income at age 65 relative to taking a line of credit when financial wealth is exhausted.

We also find that including the reversionary interest in the household's portfolio results in an increase in the optimal allocation of financial assets to stocks, regardless of the strategy adopted for decumulating the reversionary interest. For example, at a coefficient of risk aversion of five, the optimal allocation of financial assets when reverse mortgages are unavailable is 43 percent in stocks. ${ }^{4}$ But the same household will invest 68 percent of its financial wealth in stocks if it takes a reverse mortgage in the form of a lifetime income.

The remainder of the paper is organized as follows: In section one, we explain how reverse mortgages are structured and outline the literatures on reverse mortgages and on the decumulation of financial wealth in retirement. In section two, we outline the literature on returns to investments in housing. In section three, we present the VAR model that we use to determine the relationships between returns on housing and financial assets, and inflation and interest rates. In section four, we describe the alternative strategies for accessing housing wealth that are evaluated later in the paper. We present our simulation results in section five. Section six concludes.

\section{REVERSE MORTGAGES AND RETIREMENT WEALTH DECUMULATION 1.1 Reverse mortgages}

Reverse mortgages enable households to consume part of the reversionary interest in their house while continuing to live in it. HECM loans, the product with 90 percent of the market, are only available to individuals and couples aged 62 or older. Housing equity can be withdrawn in the form of an income payable for as long as the borrowers continue to live in the house, which we refer to as the "lifetime income plan," a lump sum, a line of credit, and payments for a fixed period of years. We do not comment further on the fixed period option as our calculations show that for plausible strategies it is dominated by the other options. Plans can be combined. In contrast to a conventional home loan, the interest is capitalized. The loan, plus accumulated interest,

\footnotetext{
${ }^{4}$ We assume that the household simply enjoys the imputed rent and that the house passes on death as an unintended bequest.
} 
must be repaid when neither borrower occupies the house as his principal residence. ${ }^{5}$ The amount owing is capped at the sale proceeds of the property. As the borrower is not required to make any payments on the loan, eligibility does not depend on the borrower's income or credit rating.

The loan interest rate is set at 1.5 percent above the one-year constant maturity Treasury rate. The maximum percentage of the house that can be borrowed is based on the age of the younger borrower and the yield on the ten-year constant maturity Treasury bond. The percentage is lower at younger ages because loans to younger borrowers will likely remain outstanding for longer periods and therefore accrue more interest per dollar borrowed. As previously mentioned, the percentage is also lower at higher interest rates, because at higher interest rates the interest will accrue more rapidly.

Although women statistically live longer than men, Federal law prohibits the FHA from taking gender into account when setting loan-to-valuation ratios. Interestingly, the loan limit for married couples is identical to that for single individuals, even though the joint life expectancy of a couple exceeds those of single men and women. As of 2006, the FHA further restricts loans to percentages of maximum appraised values ranging from $\$ 200,160$ in rural areas to $\$ 362,790$ in high-cost metropolitan areas. At age 65 and 14 September 2006 interest rates, these values translate into loan limits of $\$ 97,307$ to $\$ 182,934 .^{6}$

The FHA requires the borrower to purchase a mortgage insurance policy that insures the lender against the losses that would arise in the event of the loan plus accumulated interest exceeding the sale proceeds of the property. The premium is two percent of the lesser of the appraised value and the county FHA loan limit, deducted from the loan advance, plus a 0.5 percent a year interest supplement. The premium does not vary with the percentage of the maximum allowable loan that is being borrowed. Other costs include an origination fee of a maximum of two percent of the lesser of the appraised value and the county loan limit, plus closing costs that the AARP inform us average $\$ 2,000$ to $\$ 3,000$. Although not strictly a closing cost, the present value of servicing costs to age 100 is also deducted from the loan. We calculate that this

\footnotetext{
${ }^{5}$ There are also requirements relating to tax and insurance payments and maintenance of the property.

${ }^{6}$ Appraised value limits can be found at https://entp.hud.gov/idapp/html/hicostlook.cfm
} 
deduction amounts to $\$ 5,127$ at age 65 , assuming 14 September 2006 interest rates and a servicing cost of $\$ 30$ a month.

Households can return for a new loan. This is an expensive undertaking, as they would incur all their closing costs again, subject only to a credit for the mortgage insurance premium paid previously. Home mortgages are not portable, so that households with reverse mortgages might find it difficult to move - for example, to an assisted living facility.

The initial amount that can be borrowed on a line of credit equals the amount that could be borrowed as a lump sum. The credit line borrowing limit, inclusive of accumulated interest, increases at the prevailing one-year Constant Maturity Treasury Bill rate, plus a margin of 0.5 percent.

The amount of lifetime income is determined by reference to a closely related formula, again based on age and the ten-year Treasury bond rate at the time the plan commences. The monthly payments, plus accumulated interest, are charged to the borrower's account so that the amount outstanding increases over time.

An alternative to the lifetime income plan is to take a lump sum advance and use it to purchase an immediate annuity. In contrast to lifetime income plan rates, which do not take account of gender or marital status, annuity rates are higher for men and lowest of all for joint lives. In further contrast, the entire cost of an immediate annuity is paid in advance. Immediate annuities redistribute wealth from those who die soon after purchase to those who live longer than expected whereas reverse mortgages only redistribute wealth to the extent that the loan grows to exceed the value of the property. These "mortality credits" increase annuity yields, particularly at older ages.

The overall impact of these differences in product design is that the annuity strategy generally provides a higher income, particularly at older ages and for single men. To illustrate, as of 14 September 2006, the payments under the lifetime income plan commencing at age 65 equal $7.45 \%$ of the amount that could be borrowed as a lump sum. The age 65 annuity rates for single males, single females, and joint lives with a 100 percent survivor benefit are $8.47,7.88$, and 7.14 percent respectively. ${ }^{7}$ At age 85 , the

\footnotetext{
${ }^{7}$ Source www.immediateannuities.com and AARP reverse mortgage calculator.
} 
lifetime income plan yields 10.58 percent, and the annuities $17.06,15.44$, and 15.29 percent respectively.

Increases in interest rates reduce the income payable per dollar of housing wealth under both the annuity and the lifetime income strategies. Although annuity rates are more favorable at higher interest rates, this is insufficient to offset the reduction in the reverse mortgage loan to valuation ratio. ${ }^{8}$

Households that delay taking a reverse mortgage face a number of financial risks. The value of the house may decrease. The ten-year Constant Maturity Treasury rate may increase, reducing the percentages of the value of the house that can be borrowed either as a lump sum or under the lifetime income plan. And annuity rates and other asset returns may decrease so each dollar borrowed earns a lower return if invested in financial assets. These risks may be correlated. For example, an increase in interest rates may lead to a reduction in house prices.

A household can partially protect itself from these risks by setting up a line of credit immediately on retirement for subsequent use. If, by the time the household is ready to commence withdrawals, interest rates and house prices have moved in favorable directions, the household can apply for a new line of credit. If, on the other hand, interest rates and house prices have moved in unfavorable directions, the household can commence withdrawals based on the original line of credit.

\subsection{Calculations of potential consumption gains from reverse mortgages}

Previous research shows that reverse mortgages can modestly increase postretirement consumption. Venti and Wise (1991) estimated the increase at 10 percent, while Rasmussen, Megbolugbe, and Morgan (1995) estimated the increase at 25 percent among those with incomes of less than $\$ 30,000$, the higher estimate reflecting the fact that low-income homeowners often have substantial amounts of housing wealth relative to their income.

\footnotetext{
${ }^{8}$ To calculate the relationship between interest rates and annuity income, we calculated the degree of actuarial unfairness of annuities using prices quoted at www.immediateannuity.com, assuming the Treasury strip interest rate and population mortality for the appropriate birth cohort. We calculated annuity rates at other interest rates, assuming the same mortality rates and degree of actuarial unfairness. The annuity rates were then multiplied by the percentage of the value of the house that could be borrowed at the interest rate in question.
} 
The above calculations of the amounts by which reverse mortgages could increase post-retirement consumption assume as a counterfactual that housing equity passes as an unintended bequest. But Venti and Wise (2004), and Walker (2004) show that this is not generally what happens; the house is often sold, albeit usually in advanced old age, and after a precipitating shock such as the death of a spouse. Little is known about what happens to the sale proceeds. It is possible that they are spent on long-term care and medical expenses and that the house provides self-insurance against such expenses, or simply against living unusually long.

Even if the house does provide insurance against the perils of advanced old age, this is not an argument against taking a reverse mortgage, only against taking a reverse mortgage and then failing to protect oneself against those perils. ${ }^{9}$ Such protection might take the form of the purchase of annuities and long-term care insurance, or simply restricting one's current consumption. The calculation is complicated by Medicaid rules, discussed in section 4.2, which generally treat housing more favorably than financial wealth and provide an incentive to decumulate financial wealth while preserving housing wealth.

\subsection{Techniques for determining optimal asset decumulation strategies}

One approach when, as is usually the case, the problem is not analytically tractable is to use numerical optimization techniques to determine optimal strategies. This approach is computationally intensive. Housing wealth increases both the number of strategies to be considered and the number of asset classes with stochastic returns. The use of numerical optimization necessitates simplifying assumptions about asset returns and available asset allocation and decumulation strategies that detract from the realism of the model. ${ }^{10}$

The alternative approach that we adopt is to use Monte-Carlo simulations, as exemplified by Albrecht and Maurer (2002), Dus, Maurer, and Mitchell (2005), Blake, Cairns, and Dowd (2003), and Horneff, Maurer, Mitchell, and Dus (2006). The

\footnotetext{
${ }^{9}$ Stucki (2004) investigates the possibility of using reverse mortgages to manage the financial risk of longterm care.

${ }^{10}$ The distribution of asset returns is typically discretized using Gaussian quadrature, a task that becomes extremely complex when there are multiple asset classes with correlated returns that also depend on past returns.
} 
simulation approach does not consider every possible strategy, only those regarded as plausible alternatives. In particular, it assumes that households persevere with a predetermined decumulation strategy even when it may no longer be optimal to do so. Although this approach may fail to identify the optimal strategy, it might well be an advantage to only consider a subset of rule-of-thumb strategies that households might plausibly implement.

Alternative strategies are compared to a benchmark, which in the above papers was full annuitization at retirement, but in our paper is taking a reverse mortgage immediately at retirement and adding the proceeds to financial wealth. A number of yardsticks can be used to compare alternatives. For example, Albrecht and Maurer (2002) ranked strategies based on the probability that the household outlived its wealth. Although this "probability of ruin" metric is readily understandable, it can mislead. It ignores the additional return one gets if one beats the target. This was not an issue in the above paper as the alternative strategies all involved consuming a fixed amount until funds were exhausted. The use of this yardstick can also produce the paradoxical result that households with high withdrawal targets will minimize their probability of ruin by choosing extremely risky strategies when they might be better off reducing their withdrawal rate.

An alternative approach when the strategies allow for the possibility of increased consumption when returns are unusually favorable and conversely, for decreased consumption when returns are unusually poor, is to consider the magnitudes of the shortfalls and surpluses, resulting in a partial ordering of decumulation plans. Dus, Maurer, and Mitchell (2005) consider three strategies in which consumption responded to asset returns; setting current consumption equal to a fixed percentage of current wealth, to $1 / E(T)$, and to $1 / T$ where $E(T)$ is life expectancy and $T$ is the maximum possible life expectancy.

But unless one puts additional structure on the household's preferences - see Sarin and Weber (1993) - it may not be possible to provide a complete ordering of all the strategies. An alternative to the above approaches is therefore to specify a utility function and to evaluate the strategies in expected utility terms, as in Blake, Cairns, and Dowd 
(2003) and Horneff, Maurer, Mitchell, and Dus (2006). ${ }^{11}$ This is the approach that we adopt.

\section{HISTORICAL DATA}

\subsection{Comparing housing returns to those on financial assets}

The amount that the household can borrow on a reverse mortgage, what we term the reversionary interest, can be thought of as an asset. The household can "sell" this asset immediately on retirement, or can retain ownership for a period of time. The household's decision should depend on the expected return, the riskiness of that return, its covariance with the returns on other assets in the household's portfolio, and the household's consumption needs.

Its value depends on age, the Treasury bond interest rate, and the value of the house. At any given interest rate, this asset will increase in value more rapidly than the house, because the percentage of the value of the house that can be borrowed increases with age. But fluctuations in interest rates mean that the amount the household can borrow is quite volatile. Figure Two shows the amounts that could have been borrowed from 1975 to 2005 on a $\$ 200,000$ house at ages 65,75 , and 85 , net of closing costs, and assuming that the HECM program had been in existence throughout that period. The amount that could be borrowed at age 65 ranged from $5.7 \%$ of the value of the house in 1981 to $57.1 \%$ in 2002.

Table One compares the means and standard deviations of the real returns on housing, stocks, and one- and ten-year Treasury bonds over the period 1975-2005. In addition to reporting the capital return on housing, we also show the return on the reversionary interest. This equals the percentage increase in its value, in constant prices, and net of closing costs. The percentage effect of a given increase in interest rates on the amount that can be borrowed on a reverse mortgage decreases with age, so that the riskiness of the return to postponing a reverse mortgage likewise decreases with age. We therefore report the return on the reversionary interest at ages 65, 75, and 85 .

\footnotetext{
${ }^{11}$ In the above simulations, consumption varied with asset returns. If one were to attempt a utility-based analysis of strategies that involved consuming a fixed amount until financial wealth was exhausted, one would end up with an ordering that was identical to that obtained under the "probability of ruin" approach.
} 
The real return on stocks greatly exceeds that on bonds, but at the cost of higher risk. The period 1975-2005 was one that produced unusually good returns for bonds 4.37 percent, compared with an average of 2.86 percent for the period 1926-2005 obtained from an analysis of Ibbotson data. ${ }^{12}$ Stock returns were 9.18 percent during 1975-2005 compared with the long-run average of 9.07 percent, yielding an equity premium of 4.81 percent compared with a long-run average of 6.21 percent.

The average increase in real house prices over the period 1975-2005 was only 1.88 percent, with a standard deviation of 3.72 percent. We characterize this return as modest, given that the period includes the recent housing boom. Even this increase may be something of a historical aberration. Shiller (2006) calculates that there has been little increase in real house prices over the period 1890-2000. In contrast, the real return on the reversionary interest and the standard deviation of that return were very substantially higher. The means and standard deviations were 16.0 and 40.6 at age 65, 10.2 and 23.4 at age 75 , and 6.9 and 13.5 at age 85 . The higher average return to an investment in the reversionary interest reflects not only the fact that the percentage of the value of the house that can be borrowed increases with age, but also the substantial declines in nominal interest rates during this period. If interest rates had remained constant at 1975 levels, the mean returns would have been only 7.5 percent at age $65,6.5$ percent at age 75 , and 5.3 percent at age 85 . Fluctuations in interest rates also contributed substantially to the volatility of the return to the reversionary interest. Holding interest rates constant, the standard deviations fall to $4.3,4.1$, and 4.0 percent. To summarize, an investment in the reversionary interest has quite different characteristics from one in the house itself, with a much higher mean and standard deviation.

The return on the reversionary interest is initially higher than that on stocks but declines with age, while its standard deviation is higher at all but the most advanced ages. But stocks may not necessarily completely displace the reversionary interest in a mean variance efficient portfolio, as a portfolio that includes both stocks and the reversionary interest may have a lower variance than one that excludes the latter.

Households invest not in house price indices but in a particular house. Case and Shiller (1989) report substantial differences among cities in rates of appreciation over the

\footnotetext{
${ }^{12}$ The Ibbotson data are for twenty-year Treasuries. They do not collect data on ten-year Treasuries.
} 
period 1970-1986. More recently, Gyourko, Mayer, and Sinai (2004) also find evidence of persistence in differences in the rate of house-price appreciation. As anticipated house-price appreciation is an important determinant of the optimal timing of a reverse mortgage, an important implication is that optimal timing may depend on the city in which the house is located. Such differences may not necessarily imply differences in total rates of return because current house prices in areas where there is an expectation of rapid future increases may be bid up to the level where the reduction in imputed rental return just compensates for the additional anticipated capital appreciation.

There is also evidence that the returns to investing in a particular house are considerably more risky than an analysis of either national house price indices or even indices for specific cities would suggest. Flavin and Yamashita (2002) analyze PSID data for 1968 to 1992 . Every year, the PSID asks householders how much their house would sell for if it were put on the market at the date of the interview, enabling the authors to calculate annual rates of house-price appreciation. They calculated that the mean and standard deviation of the real return to individual houses, inclusive of imputed rent amounted to 6.59 and 14.24 percent respectively. They assumed that the imputed rent equals a fixed five percent of the house value, plus a constant 33 percent tax rate multiplied by self-reported property tax, so as a close approximation, the standard deviation of their capital return will also equal 0.1424 . This compares with the 0.035 standard deviation of the real return on the Census Bureau house price index.

A possible concern about their approach is that the standard deviation of returns may be inflated by reporting error. This seems to be unfounded. Case and Shiller (1989) constructed house price indices for four cities using repeat sale data, and estimated that the standard deviation of the returns on individual houses was about 0.15 , close to Flavin and Yamashita's estimate.

\subsection{The covariance of housing returns with those on financial assets}

As mentioned above, the attractiveness of the reversionary interest as an investment will depend not only on the mean and variance of its real return, but also on the covariance of that return with interest rates and with the returns on stocks and bonds. Unfortunately, there does not appear to be a stable and predictable relationship between 
interest rates, the primary determinant of bond returns, and house prices, which together with interest rates are the primary determinants of the return on the reversionary interest.

Economic theory indicates that the user cost of housing should be an important determinant of changes in house prices. The user cost will reflect interest rates, depreciation, maintenance, and taxes. It will also include anticipated changes in the value of the house. According to the user cost model, an increase in inflation will lead to an increase in nominal interest rates, holding the real interest rate constant. The increase in nominal interest rates will increase the value of the mortgage interest tax deduction, reducing the user cost of housing, and resulting in increases in house prices.

Poterba (1984) found evidence to support this hypothesis. He analyzed house price movements in the 1970s and calculated that the accelerating inflation of that decade could have accounted for a 30 percent increase in real house prices. ${ }^{13}$ In the $1980 \mathrm{~s}$, nominal interest rates and tax rates both declined, and changes to the tax code decreased the proportion of taxpayers that benefited from itemizing. These changes reduced the value of the mortgage interest tax deduction and increased user costs, as did increases in real interest rates. According to the user cost model, these trends should have led to a substantial reduction in house prices.

In fact, real house prices declined only very slightly during the 1980s. Mankiw and Weil (1989) argued that house buying by the baby boomers was the major cause of the increase in real housing prices and forecast a decline as the size of subsequent birth cohorts declined. But Poterba, Weil, and Shiller (1991) found little evidence to support explanations based on demographics or changes in either user costs or construction costs. In the absence of convincing alternative explanations, they concluded that home-owners may not have rational expectations, and may incorporate extrapolations of past appreciation into their user cost calculations. They commented on, but did not investigate in detail, the possibility that relaxations in credit constraints may have led to an increase in house prices.

Starting in the late 1990s, there was yet another rapid increase in prices in some markets. This increase coincided with exceptionally low nominal interest rates and further financial liberalization.

\footnotetext{
${ }^{13}$ Poterba examined movements in the price of housing structures, exclusive of land.
} 
We conclude that models that explain movements in house prices in one period may have very little predictive power in other periods when monetary and tax policy and the structure of financial institutions may be quite different. The above papers provide little guidance on what rate of house price appreciation to expect, and what the current relationship might be between returns on housing and financial assets.

An alternative approach is to use reduced form vector autoregressions to identify the historical relationship between the returns in housing and financial markets. Our simulations require that we capture the auto-covariance structure of asset returns, but do not depend on a particular structural model of asset price determination. An important advantage of reduced form VARs is that although forecasts made with such models assume stable relationships among the variables included in the VAR, they do not require us to make an explicit choice between competing theories of the determinants of house prices.

Sutton (2002) estimates VARs for the United States, the United Kingdom, Canada, Australia, the Netherlands, and Ireland. He finds that a 100 basis point decrease in real interest rates increases real house prices by one-half to one-and-a-half percent. $\mathrm{He}$ also finds plausibly sized effects of shocks to GNP and stock prices. For example, over a three-year time horizon, a one-percent increase in GNP is associated with a one to four percent increase in house prices, and a ten-percent increase in stock prices is associated with a one to two percent increase in house prices after three years - five percent in the United Kingdom, although these latter increases may reflect the tendency of stock prices to anticipate increases in GNP.

\section{MODELING ASSET RETURNS AND INTEREST RATES}

The Flavin and Yamashita data capture the relationship among the returns to housing, stocks, and bonds. Unfortunately, it is not suitable for our purposes. The amount that can be borrowed on a reverse mortgage depends on the yields on the oneyear Treasury bill and the ten-year Treasury bond, neither of which is included in their analysis. In addition, they make the analytically convenient assumption that returns are i.i.d., whereas Cho (1996) finds evidence of serial correlation in housing returns that might increase the riskiness of housing as an investment. 
We therefore estimate a reduced form VAR including both one- and ten-year bond yields. To avoid estimating separate equations for every housing market, we use national house price data and then test the sensitivity of our results to different assumptions about both the mean and the standard deviation of the return to housing. The covariance matrix that we obtain is then used to determine optimal asset allocations in our Monte-Carlo simulations.

Our VAR consists of equations for the nominal quarterly yield on one-year U.S. Treasury Bills, the nominal quarterly yield on ten-year U.S. Treasury Notes, the real gross quarterly rate of capital gains on home ownership (using the OFHEO repeat sales price index), real quarterly GDP growth, and the quarterly rate of consumer price inflation (using the CPI-U). The equation for each variable included eight quarterly lags of its own values as well of those of the other five variables. Following the typical treatment in the finance literature, we treated equity returns as exogenous to innovations in the processes driving the other variables, and eight quarterly lags of real quarterly equity returns (using the total return on the S\&P 500 index, with dividend reinvestment) were also included in each equation. ${ }^{14}$ Our sample period extends from the first quarter of 1975 through the fourth quarter of $2005 .^{15}$ Results from estimation of the VAR are shown in Appendix Table One.

Table Two compares the means and correlations of the returns for the historical period used in estimating the VAR with the mean of the corresponding simulated moments for the 38 year period commencing in 2006. In simulating the returns using our VAR estimates, we first take random draws for stock returns and the error terms for each equation for each quarter of the forecast period. ${ }^{16}$ These random elements are then combined with the VAR coefficients to generate 10,000 simulations of yields and asset returns for 2006 to 2043 .

\footnotetext{
${ }^{14}$ Quarterly returns and growth rates for monthly variables were calculated based on their end-of-quarter or third-month-in-quarter values.

${ }^{15}$ The sample period was dictated by availability of the OFHEO house price index.

${ }^{16} \mathrm{We}$ assumed that the quarterly stock returns were independent draws from an univariate normal distribution with mean and variance obtained from data for our estimation period. The distribution of the VAR innovations was assumed to be multivariate normal with zero means and covariances estimated from the VAR residuals.
} 


\section{CALCULATING OPTIMAL STRATEGIES WITH HOUSING WEALTH}

\subsection{Our model}

We focus on three related questions, namely, what is the optimal age to take a reverse mortgage, in what form should the household take the proceeds, and what effect does the option to take a reverse mortgage have on the optimal allocation of financial assets between stocks and bonds. We consider married couples. We assume the household has the mean amounts of financial and housing wealth for the median 20 percent of married couples turning 65 between 1994 and 2000 of $\$ 90,667$ and $\$ 101,333$ respectively, as reported by Dushi and Webb (2004). The wife is three years younger than the husband, the average for this birth cohort. The husband and wife face 1941 male and 1944 female birth cohort mortality, as forecast by the Social Security Administration. We do not consider single men or women as the median household in these categories has extremely small amounts of both housing and financial wealth.

We ignore Social Security and defined benefit pension income, or equivalently assume that this income is used to meet fixed living costs. In future work, we plan to take account of Social Security and defined benefit pension income of $\$ 17,140$ and $\$ 11,759$ respectively, the latter being fixed in nominal terms. These are the annuity equivalents of the mean amounts of Social Security and defined benefit pension wealth owned by the above households, as reported by Dushi and Webb (2004).

Our benchmark is the household's consumption assuming it takes a reverse mortgage when the husband attains age 65. In our benchmark, the household allocates its financial wealth, including the proceeds of its reverse mortgage, between stocks and bonds, maintains this allocation with annual rebalancing, and consumes 7.2 percent of its current wealth each year. The household allocates its financial wealth between stocks and bonds so as to maximize the sum of the expected utility over its lifetime, discounted by annual survival probabilities and a three percent rate of time preference. We follow the literature - see, for example, Brown and Poterba (2000) - by assuming a constant relative risk aversion utility function of the following form:

$$
U_{m}\left(C_{t}^{m}, C_{t}^{f}\right)=\frac{\left(C_{t}^{m}+\lambda C_{t}^{f}\right)^{1-\gamma}}{1-\gamma}, U_{f}\left(C_{t}^{f}, C_{t}^{m}\right)=\frac{\left(C_{t}^{f}+\lambda C_{t}^{m}\right)^{1-\gamma}}{1-\gamma}
$$


where $\lambda$ measures the jointness of consumption, $C_{t}^{m}, C_{t}^{f}$ denote the consumption of the husband and wife at time $t$, and $\gamma$ is the coefficient of risk aversion. When $\lambda$ equals one, all consumption is joint. When $\lambda$ equals zero, none of the household's consumption is joint. We assume $\lambda$ equals 0.5 .

Horneff, Maurer, Mitchell, and Dus (2006) included a bequest motive in their utility function. We chose not to include a bequest motive as there is no consensus as to how it should enter into the utility function and all of our strategies result in at least some likelihood of a bequest.

We assume that management charges on stocks and bonds amount to 43 and 25 basis points respectively. ${ }^{17}$ We assume that households invest in corporate bonds at a fixed 100 basis point premium to the ten-year Treasury bond. We disregard income tax, both for simplicity and also because the median 20 percent of married couple households are unlikely to face significant liabilities.

The expected real returns on stocks and bonds in the simulation period are 9.39 and 3.80 percent respectively before management charges, with standard deviations of 16.9 and 10.27 respectively. It follows that there is a high probability that the value of the household's assets will decline, although the household will never exhaust them. The assumed withdrawal rate is somewhat higher than the four percent or so that is often suggested by financial advisers, but is chosen to facilitate comparison with Horneff, Maurer, Mitchell, and Dus (2006). ${ }^{18}$ We also report benchmarks and alternatives using both 5.0 and 10.0 percent withdrawal rates but find that the choice of decumulation rate has little effect on the optimal strategy.

We then compare our base case with the following alternatives:

\section{Simulations with a lump sum advance}

The household postpones taking its reverse mortgage until age 70, 75, 80, or 85 . In each period prior to taking its reverse mortgage, the household consumes 7.2 percent

\footnotetext{
${ }^{17}$ These amounts equal the current expense ratios on Vanguard Diversified Equity and Long-Term Investment Grade Bond funds.

${ }^{18}$ A summary of withdrawal rate recommendations is posted at http://www.retireearlyhomepage.com/safewith.html. Horneff et al chose 7.2 percent to facilitate comparison with the purchase of an immediate annuity.
} 
of the current total value of its financial wealth and reversionary interest. If the household has insufficient financial wealth to pay for planned consumption, it takes a reverse mortgage immediately.

To implement this strategy, the household must be able to ascertain the value of their house and be able to determine the amount they could obtain on a reverse mortgage. This information is readily available on the internet. ${ }^{19}$

When the household takes a reverse mortgage it adds the proceeds to its stock of financial wealth and from then on consumes 7.2 percent a year of its financial wealth. On taking a reverse mortgage, it is allowed to select a revised allocation of financial wealth between stocks and bonds, which it maintains with annual rebalancing until death.

HECM rules permit a household to reapply for an additional loan if the current house value and ten-year Treasury bond interest rate permit. It is difficult to determine the optimal strategy in relation to further advances - should it take a small advance now or delay in the hope of being able to obtain a larger advance later. Our simulations indicate that transaction costs are such that it will only rarely be possible for households to obtain significant further advances, and we therefore assume that they only take a single loan for the maximum possible amount.

\section{Simulations with a line of credit}

We consider two alternatives. In the first, the household initially consumes 7.2 percent of the current total value of its financial wealth and reversionary interest. The household establishes a line of credit when it no longer has sufficient financial wealth to pay for planned consumption. It then takes a periodic withdrawal equal to 7.2 percent of the total of the current balance available for withdrawal on the line of credit plus any residual financial wealth. In the second, the household establishes its line of credit at age 65 and immediately commences drawing at a rate equal to 7.2 percent of the current undrawn balance.

\section{Simulations with a lifetime income}

\footnotetext{
${ }^{19}$ www.zillow.com enables homeowners to track the value of their house, and the AARP has an online reverse mortgage calculator.
} 
We consider two alternatives. In the first, the household again initially consumes 7.2 percent of the current total value of its financial wealth and reversionary interest. The household applies for a lifetime income when it no longer has sufficient financial wealth to pay for planned consumption. This strategy can result in a significant change in income when the reverse mortgage is taken, as the income payment rate will typically be higher than the 7.2 percent withdrawal rate being taken until that time. But the monthly income for life is fixed in nominal terms so that the boost to income declines over time. In the second, the household takes a lifetime income immediately on retirement. In addition to consuming its lifetime income, it consumes 7.2 percent a year of its financial wealth.

\subsection{Medicaid and health shocks}

Medicaid eligibility rules treat housing more favorably than financial assets. In general, individuals will only become eligible for Medicaid after they have spent almost all of their financial assets. In contrast, housing wealth may be passed to a surviving spouse. Medicaid rules relating to expenditure on long-term care are somewhat less stringent, but still favor housing over financial wealth for many households. Depending on the state of residence, financial wealth of $\$ 19,908$ or $\$ 99,540$ is completely protected under so called "spousal protection rules" and partial protection may be available up to $\$ 199,080$. Households wishing to protect assets for the benefit of a surviving spouse will often have an incentive to hold housing in preference to financial wealth. We do not model these incentives as they depend on the household's assessment of the probabilities of incurring expenditure on medical and long-term care, their state of residence, financial assets, and the amounts of other income received by the husband and wife.

\section{SIMULATION RESULTS}

\subsection{Optimal reverse mortgage strategies - base case}

Table Three reports our base case results. We calculate the household's expected utility if it takes a reverse mortgage at age 65 and invests the proceeds in a utility maximizing portfolio of stocks and bonds (we term this the default strategy), and compare this with the expected utilities of alternative strategies. These comprise taking a 
reverse mortgage at ages $70,75,80$, or 85 , and taking a line of credit or a lifetime income either at age 65 or when the household's financial wealth is exhausted. We calculate reverse mortgage equivalent wealth. As mentioned previously, this is the factor by which the wealth of a household choosing the default strategy must be multiplied so that its expected utility equals that of the household choosing the alternative. When reverse mortgage equivalent wealth of a particular strategy exceeds 1.00 , that strategy offers a higher expected utility than the default. This measure is analogous to the calculation of "annuity equivalent wealth" in Brown and Poterba (2000), the amount the household would require by way of compensation for the loss of the right to annuitize its retirement wealth.

The only strategies that offer reverse mortgage equivalent wealth in excess of 1.00 are those that involve taking a lifetime income, and then only at higher degrees of risk aversion. At lower degrees of risk aversion, the household prefers to sell its reversionary interest and invest the proceeds in stocks, the additional return more than compensating for the additional risk. It seems unlikely that many households would be attracted by this strategy, as evidenced by younger households' reluctance to leverage their housing wealth to invest in the stock market.

The strategy of taking a lifetime income once financial wealth is exhausted results in very similar reverse mortgage equivalent wealth to that of taking a lifetime income at age 65 . In the former case, the household decumulates its risky financial wealth more rapidly, but retains an investment in the risky reversionary interest. As mentioned in section two, an alternative to taking a lifetime income from a reverse mortgage is to take a lump sum and use that to purchase an immediate annuity from an insurance company. At age 65, these two alternatives produce very similar incomes, but at older ages, the strategy of combining a reverse mortgage with an immediate annuity yields a substantially higher income. So the dominant strategy is probably to spend down one's financial wealth, take a reverse mortgage, and use the proceeds to buy an annuity.

We are informed by the National Reverse Mortgage Lenders Association that the great majority of borrowers choose the line of credit option, typically in advanced old age. The line of credit option provides a lower expected utility than the lifetime income option, particularly if taken when financial wealth is exhausted. As we discuss in more 
detail later, at our assumed withdrawal rate of 7.2 percent, the initial income produced by the line of credit is less than that which can be obtained under the lifetime income option. Furthermore, instead of providing the household with a stable level income, the amount of the income fluctuates with movements in the interest rate, and will decline over time at an interest rate of less than 7.2 percent.

The variations in reverse mortgage equivalent wealth can be substantial. Relative to the default, a household is 8.5 percent better off if it takes a reverse mortgage as a lifetime income when it has exhausted its financial wealth, assuming a coefficient of risk aversion of five. But at the same coefficient of risk aversion, it would be 18.4 percent worse off if it took a line of credit when its financial wealth was exhausted.

Investment allocations vary in predictable ways. In the base case, the optimal allocation to equities varies from 100 percent at a coefficient of risk aversion of two, to 43 percent at a coefficient of risk aversion of five. These investment allocations also apply when we close the reverse mortgage market and assume that the house passes as an unintended bequest. Households taking a lifetime income or a line of credit at age 65 allocate larger proportions of their financial wealth to stocks -68 and 61 percent respectively at a coefficient of risk aversion of five. Households that postpone taking a lifetime income or a line of credit until they have exhausted their financial wealth invest even lager percentages in stocks - 100 and 93 percent respectively at a coefficient of risk aversion of five. Although they start out with the same amount of financial wealth as households that take a lifetime income or line of credit at age 65, they decumulate their financial wealth more rapidly. On average, over the course of their retirement, financial wealth constitutes a smaller proportion of total wealth, and they respond by investing that wealth more aggressively. For the same reason, households that postpone taking a lump sum invest 100 percent of their financial wealth in stocks prior to taking a reverse mortgage, decreasing to 88 to 45 percent subsequently.

Figures 3 (a) and (b) show the means and standard deviations of the income flows. We present results calculated at a coefficient of risk aversion of five. The strategy of postponing taking a reverse mortgage until financial wealth is exhausted, and then taking the reverse mortgage in the form of a lifetime income provides the highest mean income at almost all ages, but with a standard deviation that sharply increases at very 
advanced ages. The household holds two risky assets: the reversionary interest and a portfolio of financial assets that is 100 percent invested in stocks. The strategy of taking a lifetime income at age 65 provides a lower mean income at older ages, but at substantially reduced risk at all ages because the household is no longer exposed to the risks of investing in the reversionary interest. Taking a line of credit when financial wealth is exhausted, the strategy adopted by most households, performs particularly badly, being among the riskiest strategies at all but the oldest ages, while providing a modest and declining income.

The two lifetime income strategies can each be compared with the corresponding lump sum strategy. Taking a lifetime income at age 65 provides a higher average income at all ages than taking a lump sum, albeit at slightly higher risk at older ages. Taking a lifetime income when financial wealth is exhausted is clearly preferable to taking a lump sum when financial wealth is exhausted, providing a much higher average income at what are similar levels of risk at all but the most advanced ages. The lifetime income plan provides a high level of income that is guaranteed for life.

The numbers at other coefficients of risk aversion reflect the impact of risk aversion on portfolio allocations to equities. At a coefficient of risk aversion of two, both the mean and the standard deviation of the age 65 lump sum strategy are higher than when the coefficient of risk aversion equals five. But the mean and standard deviation of the income from the strategy of taking a lifetime income when financial wealth is exhausted is unchanged because households adopting this strategy invest 100 percent in equities regardless of degree of risk aversion.

\subsection{Optimal Strategies - Alternative assumptions regarding asset returns}

We consider the implications of alternative assumptions about asset returns. Although our results vary in predictable ways, we find that our key conclusion, that taking a lifetime income either at 65 or when financial wealth is exhausted dominates the alternatives, still holds.

Table Four compares reverse mortgage equivalent wealth under alternative assumptions regarding asset returns. When the housing return is increased by two percent, it becomes relatively more attractive to postpone taking a reverse mortgage. But 
at coefficients of risk aversion of three, four, and five, the optimal strategy is still to take a lifetime income, although now it is clearly more advantageous to delay until financial wealth is exhausted. At a coefficient of risk aversion of two, the dominant strategy remains to take a reverse mortgage at age 65 and invest everything in stocks.

When the housing return is decreased by two percent, the optimal strategy is to take a lifetime income at age 65 unless the coefficient of risk aversion equals two, when the optimal strategy is again to take a lump sum at age 65 and invest everything in stocks.

When the stock return is decreased by three percent, the optimal strategy is to take a lifetime income when financial wealth is exhausted, regardless of degree of risk aversion. The second choice is to take a lifetime income at age 65, again regardless of degree of risk aversion. The lifetime income option is always preferable to taking a lump sum at age 65 and investing the proceeds in stocks. The optimal portfolio allocation to stocks decreases substantially when we assume a lower return on stocks.

At a five percent withdrawal rate, the optimal strategy is to take a lifetime income at age 65. The lifetime income now offers a substantially higher immediate income than the alternatives. At a ten percent withdrawal rate, the optimal strategy is again to take a lifetime income, there now being little difference between taking one immediately and delaying until the household's financial wealth is exhausted. The withdrawal rate is so high that households that do not take a lifetime income risk very low income in advanced old age.

When we increase the standard deviation of housing returns to 15 percent, we find that it is optimal for all but the most risk tolerant to take a lifetime income at age 65 . The most risk tolerant should take an immediate reverse mortgage and again invest the proceeds entirely in stocks. But delaying taking a lifetime income now becomes highly unattractive.

\section{CONCLUSIONS}

Housing constitutes much of the non-pension wealth of the majority of households. As a result of inadequate savings rates and declines in Social Security replacement rates, increasing numbers of households are likely to enter retirement with insufficient pension and financial wealth to maintain their standard of living. 
Reverse mortgages offer a mechanism whereby such households can augment their income. Eschtruth, Sun, and Webb (2006) calculate that if the median household took a reverse mortgage at age 65 in the form of a lifetime income, it would receive a lifetime income of $\$ 364$ a month, an amount that could contribute modestly to the household's income. ${ }^{20}$

Households can take a reverse mortgage as a lump sum, a lifetime income, or a line of credit. Our simulations show that households would be substantially better off taking their reverse mortgage as a lifetime income, a result that is robust to alternative assumptions about rates of return, and one that mirrors findings in the annuitization literature. But households appear to overwhelmingly choose the line of credit option. Their reluctance to take the lifetime income option mirrors the reluctance of households to annuitize their financial wealth.

\footnotetext{
${ }^{20}$ At 14 September 2006 interest rates, based on an assumed housing wealth of $\$ 125,000$ with no preexisting mortgage.
} 


\section{References}

Albrecht, Peter and Raimond Maurer. 2002. "Self Annuitization, Ruin Risk in Retirement and Asset Allocation: The Annuity Benchmark." Journal of Pension Economics and Finance 1(3), 269-288.

Blake, David, Andrew Cairns, and Kevin Dowd. 2003. "Pensionmetrics 2: Stochastic Pension Design During the Distribution Phase." Insurance Mathematics \& Economics 33 (1), 29-47.

Brown, Jeffrey and James Poterba. 2000. "Joint Life Annuities and Annuity Demand by Married Couples.” Journal of Risk and Insurance 67(4), 527-553.

Caplin, Andrew. 2002. "Turning Assets Into Cash: Problems and Prospects in the Reverse Mortgage Industry.” In Olivia S. Mitchell, Zvi Bodie, P. Brett Hammond, and Stephen Zeldes eds. Innovations in Retirement Financing University of Philadelphia Press, 234-253.

Case, Karl E. and Robert Shiller J. 1989. "The Efficiency of the Market for Single Family Homes.” American Economic Review 79(1), 125-137.

Cho, Man. 1996. "House Price Dynamics: A Survey of Theoretical and Empirical Issues." Journal of Housing Research 7(2), 145-172.

Dus, Ivica, Raimond Maurer, and Olivia Mitchell. 2005. "Betting on Death and Capital Markets in Retirement: A Shortfall Risk Analysis of Life Annuities Versus Phased Withdrawal Plans." Financial Services Review 14(3), 169-196.

Dushi, Irena and Anthony Webb. 2004. "Household Annuitization Decisions: Simulations and Empirical Analyses." Journal of Pension Economics and Finance 3(2), 109-143.

Eschtruth, Andrew D., Wei Sun and Anthony Webb. 2006. "Will Housing Wealth Rescue the Baby Boomers?" Issue Brief 54. Chestnut Hill, MA: Center for Retirement Research at Boston College

Flavin, Marjorie and Takashi Yamashita. 2002. "Owner Occupied Housing and the Composition of the Household Portfolio." American Economic Review 92(1), 345-362.

Gyourko, Joseph, Christopher Mayer, and Todd Sinai. 2006. "Superstar Cities." National Bureau of Economic Research Working Paper No.12355.

Horneff, Wolfram J., Raimond Maurer, Olivia S Mitchell and Ivica Dus. 
2006."Optimizing the Retirement Portfolio: Asset Allocation, Annuitization, and Risk Aversion.” Working Paper 12392. Cambridge, MA: National Bureau of Economic Research.

Mankiw, Gregory N. and David N. Weil. 1989. "The Baby Boom, the Baby Bust, and the Housing Market." Regional Science and Urban Economics 19(2), 235-258.

Merrill Sally R., Meryl Finkel, and Nandinee K. Kutty. 1994. "Potential Beneficiaries from Reverse Mortgage Products for Elderly Homeowners: An Analysis of American Housing Survey Data." Journal of the American Real Estate and Urban Economics Association 22(2), 257-299.

Mitchell, Olivia and James F. Moore. 1997. "Retirement Wealth Accumulation and Decumulation: New Developments and Outstanding Opportunities." Working Paper 6178. Cambridge, MA: National Bureau of Economic Research.

Poterba, James M. 1984. “Tax Subsidies to Owner Occupied Housing: An Asset Market Approach.” Quarterly Journal of Economics 99(4), 729-752

Poterba, James M., David N. Weil, and Robert Shiller. 1991. "House Price Dynamics: The Role of Tax Policy and Demography." Brookings Papers on Economic Activity 1991(2), 143-203.

Rasmussen, David W., Isaac F Megbolugbe, and Barbara A. Morgan. 1995. "Using the 1990 Public Use Microdata Sample to Estimate Potential Demand for Reverse Mortgage Products." Journal of Housing Research 6 (1), 1-23.

Sarin, Rakesh and Martin Weber. 1993. "Risk-Value Models." European Journal of Operational Research (72), 135-149.

Shiller, Robert J. 2006. "Long-Term Perspectives on the Current Boom in Home Prices.” The Economists' Voice 3(4), Article 4.

Sun, Wei, Robert Triest, and Anthony Webb. 2006. "Will Housing Wealth Rescue the Baby Boomers?" Issue Brief, forthcoming. Chestnut Hill, MA: Center for Retirement Research at Boston College

Sutton, Gregory D. 2002. "Explaining Changes in House Prices." BIS Quarterly Review $0(0), 46-55$.

Venti, Steven F. and David A. Wise. 1991. "Aging and the Income Value of Housing Wealth.” Journal of Public Economics 44(3), 371-397.

Venti, Steven F. and David A. Wise. 2004. "Aging and Housing Equity: Another Look." Perspectives on the Economics of Aging. Ed. David A. Wise. University of Chicago Press, 127-175. 
Walker, Lina. 2004. "Elderly Households and Housing Wealth: Do They Use It or Lose It?” Working Paper 2004-01. Ann Arbor, MI: University of Michigan. 


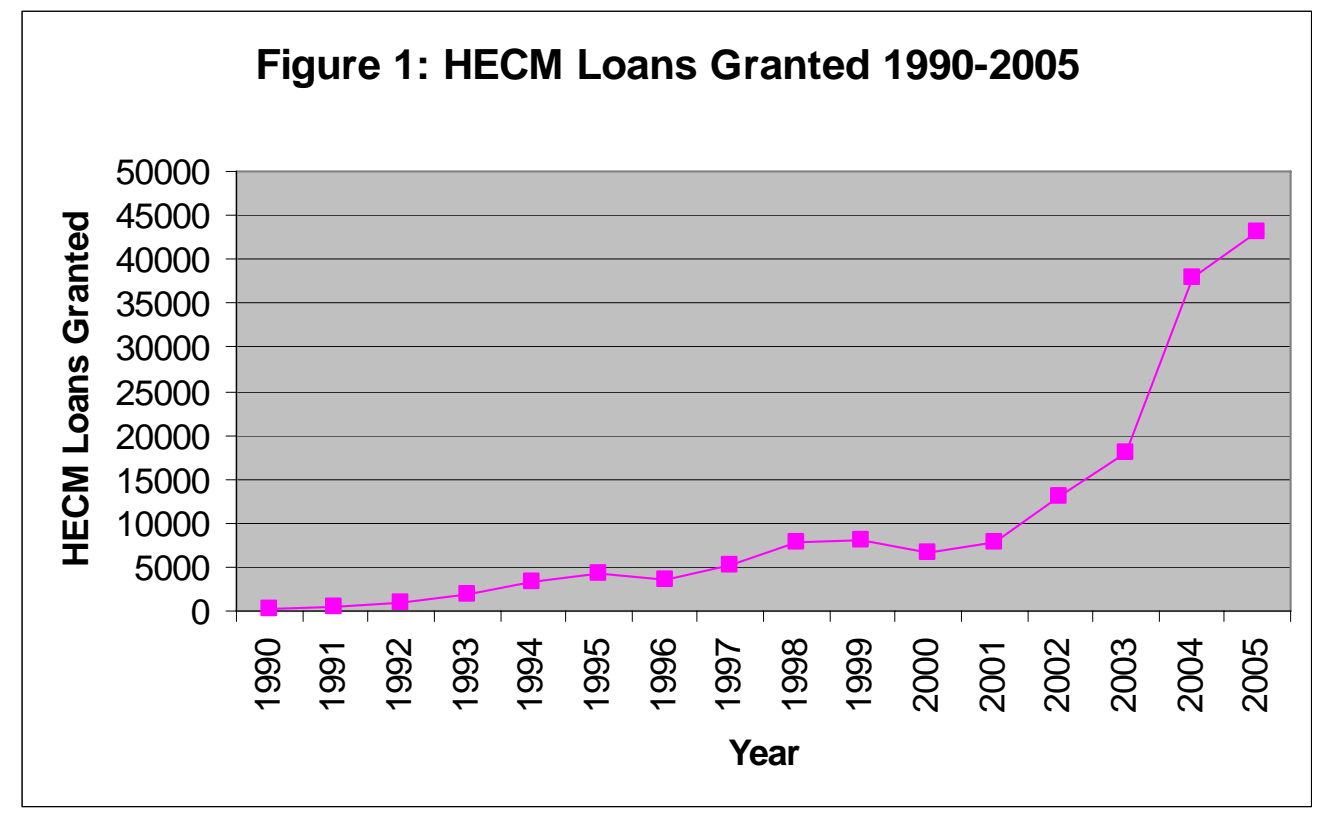

Source: National Reverse Mortgage Lenders Association/U.S.Department of Housing and Urban Development Fiscal Year October 1 - September 30

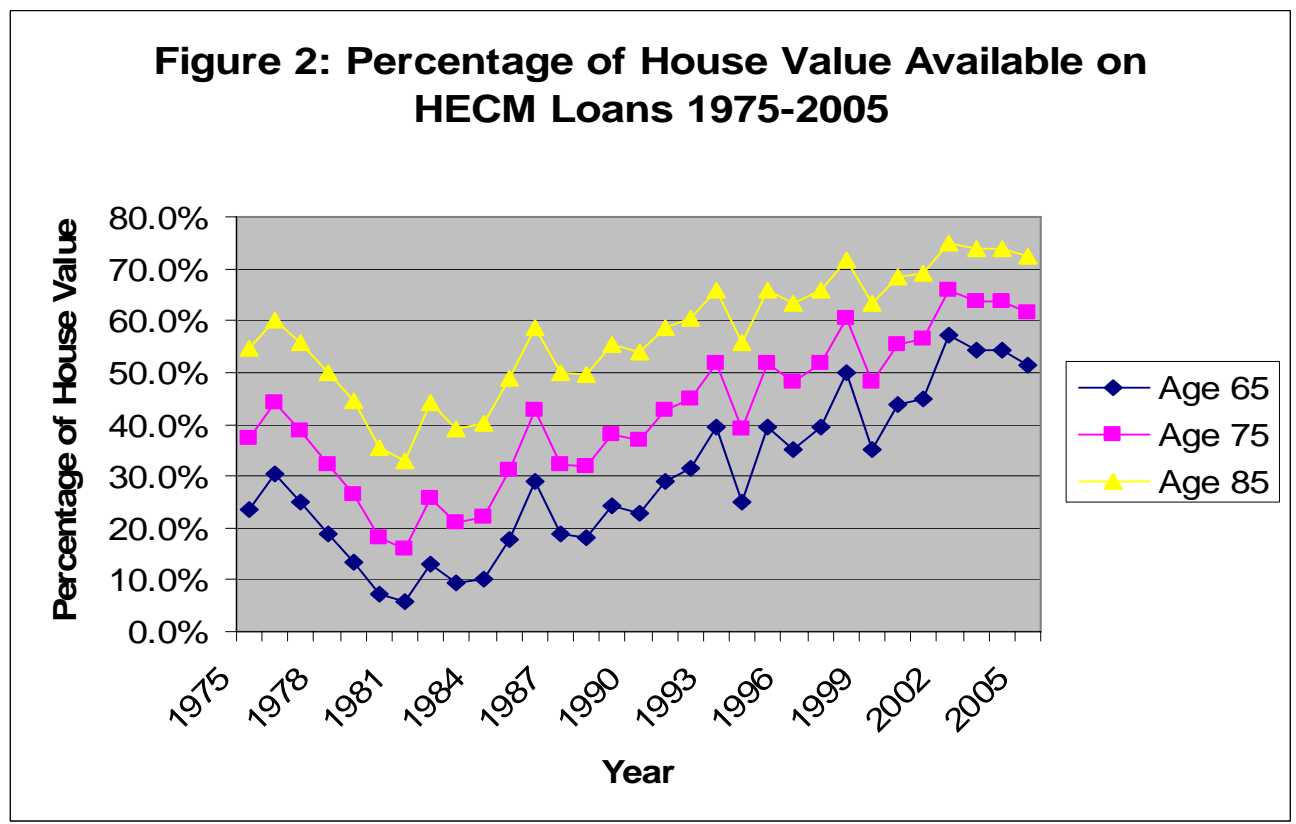

Notes: 1) This figure assumes a $\$ 200,000$ house, a 1.5 percent lender's margin and the closing cost estimates used by the AARP in their online reverse mortgage loan calculator. These closing costs are an origination fee and a mortgage insurance premium each equal to 2 percent of the home's appraised value, miscellaneous closing costs of $\$ 2,074$, and a servicing fee of \$30 per month. 2) HECM loans have only been available since 1990, so amounts for 1975 to 1989 represent the percentages that could have been borrowed had they been available. 
Figure 3 (a) Mean Returns to Alternative Decumulation Strategies-CRRA $=5$
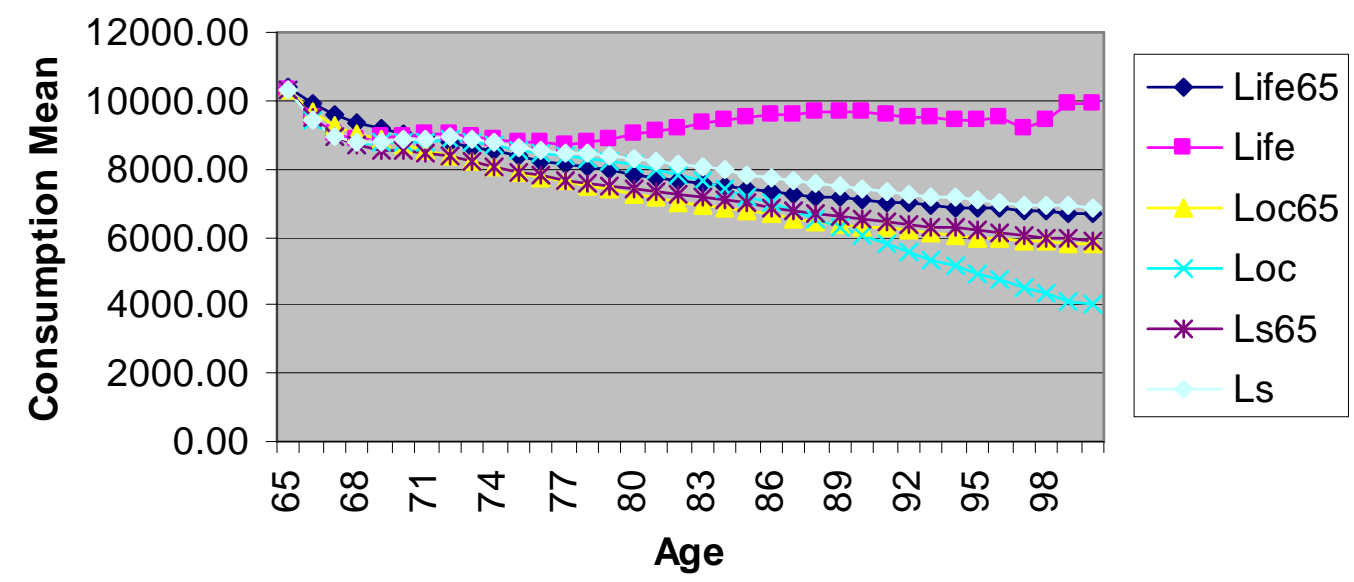

Figure 3 (b) Standard Deviation of Returns to Alternative Decumulation Strategies-CRRA=5
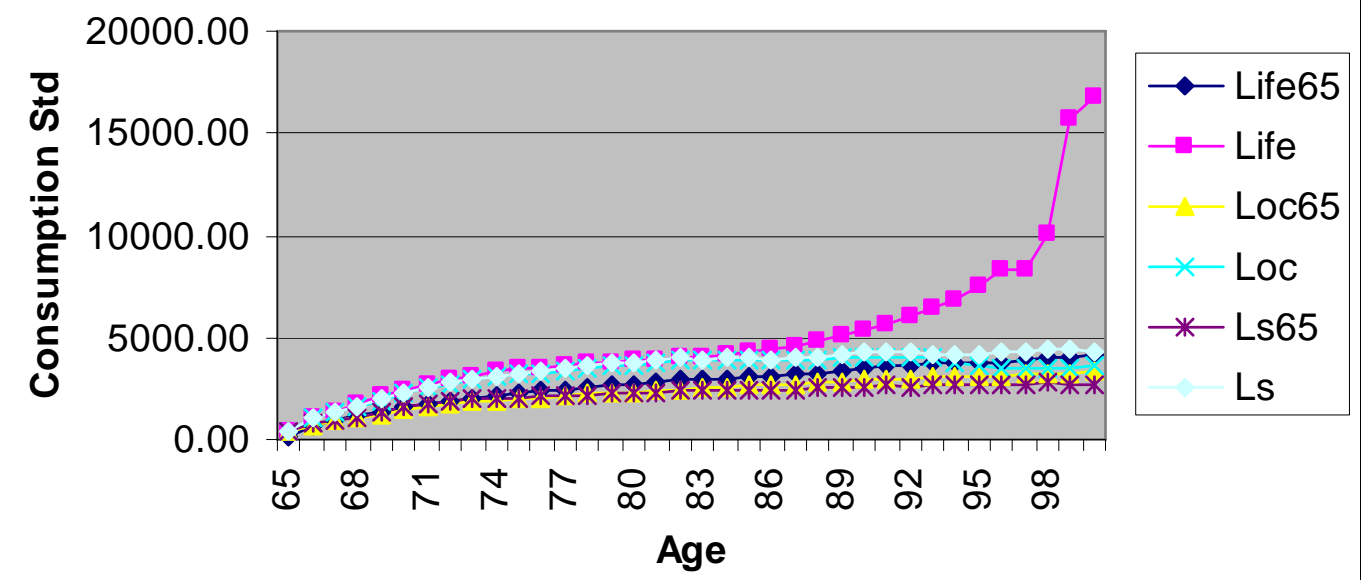


\begin{tabular}{lcc} 
Table 1: Real Returns on Housing and Financial Assets & 1975-2005 \\
& Mean & Standard Deviation \\
\cline { 2 - 3 } One Year Treasury Bill & $2.2 \%$ & $2.0 \%$ \\
Ten Year Treasury Bond & $4.4 \%$ & $10.3 \%$ \\
S\&P 500 incl dividends & $9.2 \%$ & $15.5 \%$ \\
Housing - Capital Return & $1.9 \%$ & $3.7 \%$ \\
Housing - Reversionary Interest & & \\
Postpone from 65 to 66 & $16.0 \%$ & $40.6 \%$ \\
Postpone from 75 to 76 & $10.2 \%$ & $23.4 \%$ \\
Postpone from 85 to 86 & $6.9 \%$ & $13.5 \%$ \\
\hline
\end{tabular}

Table 2: Comparison of Historical and Simulated Data

\begin{tabular}{|c|c|c|c|c|c|c|}
\hline & $\begin{array}{c}\text { One year } \\
\text { nominal } \\
\text { yield }\end{array}$ & $\begin{array}{c}\text { Ten year } \\
\text { nominal } \\
\text { yield }\end{array}$ & $\begin{array}{l}\text { Real } \\
\text { stock } \\
\text { return }\end{array}$ & $\begin{array}{l}\text { Real } \\
\text { house } \\
\text { price } \\
\text { appn }\end{array}$ & Inflation & $\begin{array}{c}\text { real GDP } \\
\text { growth }\end{array}$ \\
\hline 1975-2005 Mean & 6.593 & 7.610 & 9.178 & 1.880 & 4.359 & 3.195 \\
\hline SD & 3.292 & 2.656 & 15.483 & 3.715 & 2.980 & 2.027 \\
\hline \multirow{2}{*}{$\begin{array}{c}\text { 2006-2045 Mean } \\
\text { SD } \\
\end{array}$} & 6.653 & 7.457 & 9.387 & 2.097 & 4.311 & 2.846 \\
\hline & 2.954 & 2.304 & 16.901 & 3.567 & 2.606 & 2.186 \\
\hline \multicolumn{7}{|l|}{ Historical correlatiom } \\
\hline One year yield & 1.000 & & & & & \\
\hline Ten year yield & 0.924 & 1.000 & & & & \\
\hline Stock return & -0.006 & -0.038 & 1.000 & & & \\
\hline House price appn & -0.574 & -0.632 & -0.055 & 1.000 & & \\
\hline Inflation & 0.790 & 0.663 & -0.223 & -0.452 & 1.000 & \\
\hline real GDP growth & -0.056 & -0.050 & 0.133 & 0.323 & -0.194 & 1.000 \\
\hline \multicolumn{7}{|l|}{ Simulated correlation } \\
\hline One year yield & 1.000 & & & & & \\
\hline Ten year yield & 0.786 & 1.000 & & & & \\
\hline Stock return & 0.201 & 0.330 & 1.000 & & & \\
\hline House price appn & -0.851 & -0.979 & -0.325 & 1.000 & & \\
\hline Inflation & 0.064 & -0.550 & -0.234 & 0.408 & 1.000 & \\
\hline real GDP growth & 0.144 & 0.722 & 0.304 & -0.611 & -0.951 & 1.000 \\
\hline
\end{tabular}


Table 3: Results - Base Case

\begin{tabular}{|c|c|c|c|c|c|}
\hline Strategy & Coefficient of risk aversion & 2 & 3 & 4 & 5 \\
\hline \multirow[t]{23}{*}{ Lump sum at age } & 65 Mean income & 11885 & 10396 & 8747 & 7752 \\
\hline & Standard deviation & 8125 & 5411 & 3172 & 2300 \\
\hline & Investment allocation & 100 & 82 & 59 & 43 \\
\hline & 70 Equivalent wealth & 0.889 & 0.932 & 0.957 & 0.96 \\
\hline & Mean income & 9512 & 8782 & 8389 & 8158 \\
\hline & Standard deviation & 5102 & 3630 & 3084 & 2856 \\
\hline & Investment allocation at 65 & 100 & 100 & 100 & 100 \\
\hline & Investment allocation at 70 & 88 & 66 & 53 & 45 \\
\hline & 75 Equivalent wealth & 0.878 & 0.921 & 0.934 & 0.920 \\
\hline & Mean income & 9169 & 8781 & 8577 & 8436 \\
\hline & Standard deviation & 4557 & 3736 & 3431 & 3270 \\
\hline & Investment allocation at 65 & 100 & 100 & 100 & 100 \\
\hline & Investment allocation at 75 & 85 & 65 & 54 & 46 \\
\hline & 80 Equivalent wealth & 0.878 & 0.931 & 0.956 & 0.96 \\
\hline & Mean income & 9442 & 9196 & 9070 & 8859 \\
\hline & Standard deviation & 4518 & 3945 & 3722 & 3445 \\
\hline & Investment allocation at 65 & 100 & 100 & 100 & 100 \\
\hline & Investment allocation & 86 & 67 & 57 & 50 \\
\hline & 85 Equivalent wealth & 0.877 & 0.933 & 0.960 & 0.96 \\
\hline & Mear & 9962 & 9754 & 9644 & 9467 \\
\hline & Stanc & 5058 & 4482 & 4238 & 3977 \\
\hline & Inves & 100 & 100 & 100 & 100 \\
\hline & t allocation & 90 & 71 & 60 & 54 \\
\hline \multirow[t]{4}{*}{ Line of credit at 65} & Equivalent wealth & 0.918 & 0.962 & 0.971 & 0.971 \\
\hline & Mean income & 9622 & 9622 & 8554 & 7672 \\
\hline & Stand & 5299 & 5299 & 3487 & 2484 \\
\hline & Inves & 100 & 100 & 80 & 61 \\
\hline \multirow{4}{*}{$\begin{array}{l}\text { Line of credit } \\
\text { when financial } \\
\text { wealth exhasuted }\end{array}$} & Equivalent wealth & 0.817 & 0.851 & 0.847 & 0.816 \\
\hline & Mean income & 8122 & 8122 & 8122 & 7864 \\
\hline & Standard deviation & 3867 & 3867 & 3867 & 3481 \\
\hline & Investment allocation & 100 & 100 & 100 & 93 \\
\hline \multirow[t]{4}{*}{ Lifetime income at 6} & 65 Equivalent wealth & 0.949 & 1.007 & 1.030 & 1.045 \\
\hline & Mean & 9837 & 9837 & 9125 & 8197 \\
\hline & Stan & 5271 & 5271 & 3994 & 2746 \\
\hline & ocation at 6 & 100 & 100 & 87 & 68 \\
\hline \multirow{4}{*}{$\begin{array}{l}\text { Lifetime income } \\
\text { when financial } \\
\text { wealth exhausted }\end{array}$} & Equivalent wealth & 0.910 & 0.990 & 1.048 & 1.085 \\
\hline & Mear & 9204 & 9204 & 9204 & 9204 \\
\hline & Standard deviation & 4446 & 4446 & 4446 & 4446 \\
\hline & Investment allocation at 65 & 100 & 100 & 100 & 100 \\
\hline
\end{tabular}


Table 4: Comparison of Reverse Mortgage Equivalent Wealth

\begin{tabular}{lrrrrrr}
\multicolumn{2}{l}{$\begin{array}{l}\text { Risk aversion } \\
\text { Asset return assumptions }\end{array}$} & exhausted & $\begin{array}{r}\text { Lifetime income } \\
\text { As5 exhausted }\end{array}$ & $\begin{array}{c}\text { Line of credit } \\
65 \text { exhausted }\end{array}$ \\
\hline \hline Base case & 2 & 0.876 & 0.949 & 0.910 & 0.918 & 0.817 \\
& 3 & 0.933 & 1.007 & 0.990 & 0.962 & 0.851 \\
& 4 & 0.960 & 1.030 & 1.048 & 0.971 & 0.847 \\
& 5 & 0.957 & 1.045 & 1.085 & 0.971 & 0.816 \\
\hline House return +2\% & 2 & 0.950 & 0.949 & 0.987 & 0.918 & 0.878 \\
& 3 & 1.017 & 1.007 & 1.078 & 0.962 & 0.925 \\
& 4 & 1.050 & 1.030 & 1.148 & 0.971 & 0.931 \\
& 5 & 1.059 & 1.045 & 1.199 & 0.971 & 0.912 \\
\hline House return -2\% & 2 & 0.803 & 0.949 & 0.834 & 0.918 & 0.757 \\
& 3 & 0.843 & 1.007 & 0.898 & 0.962 & 0.775 \\
& 4 & 0.854 & 1.030 & 0.940 & 0.971 & 0.755 \\
& 5 & 0.841 & 1.045 & 0.966 & 0.971 & 0.720 \\
\hline Stock return -3\% & 2 & 1.017 & 1.025 & 1.083 & 0.980 & 0.937 \\
& 3 & 1.013 & 1.037 & 1.124 & 0.982 & 0.921 \\
& 4 & 0.992 & 1.045 & 1.149 & 0.979 & 0.889 \\
\hline $5 \%$ withdrawal rate & 5 & 0.961 & 1.054 & 1.168 & 0.974 & 0.851 \\
\hline $10 \%$ withdrawal rate & 2 & 0.954 & 1.011 & 0.905 & 0.927 & 0.870 \\
& 3 & 0.959 & 1.064 & 0.956 & 0.973 & 0.918 \\
& 4 & 0.966 & 1.081 & 0.983 & 0.993 & 0.939 \\
& 5 & 0.961 & 1.083 & 0.993 & 1.002 & 0.940 \\
\hline standard deviation & 2 & 0.961 & 0.955 & 0.877 & 0.905 & 0.726 \\
& 3 & 0.987 & 1.074 & 1.009 & 0.939 & 0.712 \\
& 4 & 1.001 & 1.173 & 1.145 & 0.939 & 0.676 \\
& 5 & 0.985 & 1.261 & 1.283 & 0.936 & 0.653 \\
\hline
\end{tabular}


Appendix Table 1: VAR Estimation Results

\begin{tabular}{|c|c|c|c|c|c|c|}
\hline $\begin{array}{c}\text { Dep Var = one } \\
\text { year interest rate }\end{array}$ & Dep & $=10$ & $\begin{array}{l}\text { Dep } \\
\text { hou }\end{array}$ & $\begin{array}{l}=\text { real } \\
\text { return }\end{array}$ & & $\begin{array}{l}\text { Dep Var = real } \\
\text { GDP growth }\end{array}$ \\
\hline Coeff & Coeff & $\mathrm{SE}$ & Coeff & $\mathrm{SE}$ & Coeff & Coeff \\
\hline
\end{tabular}

One Year rate

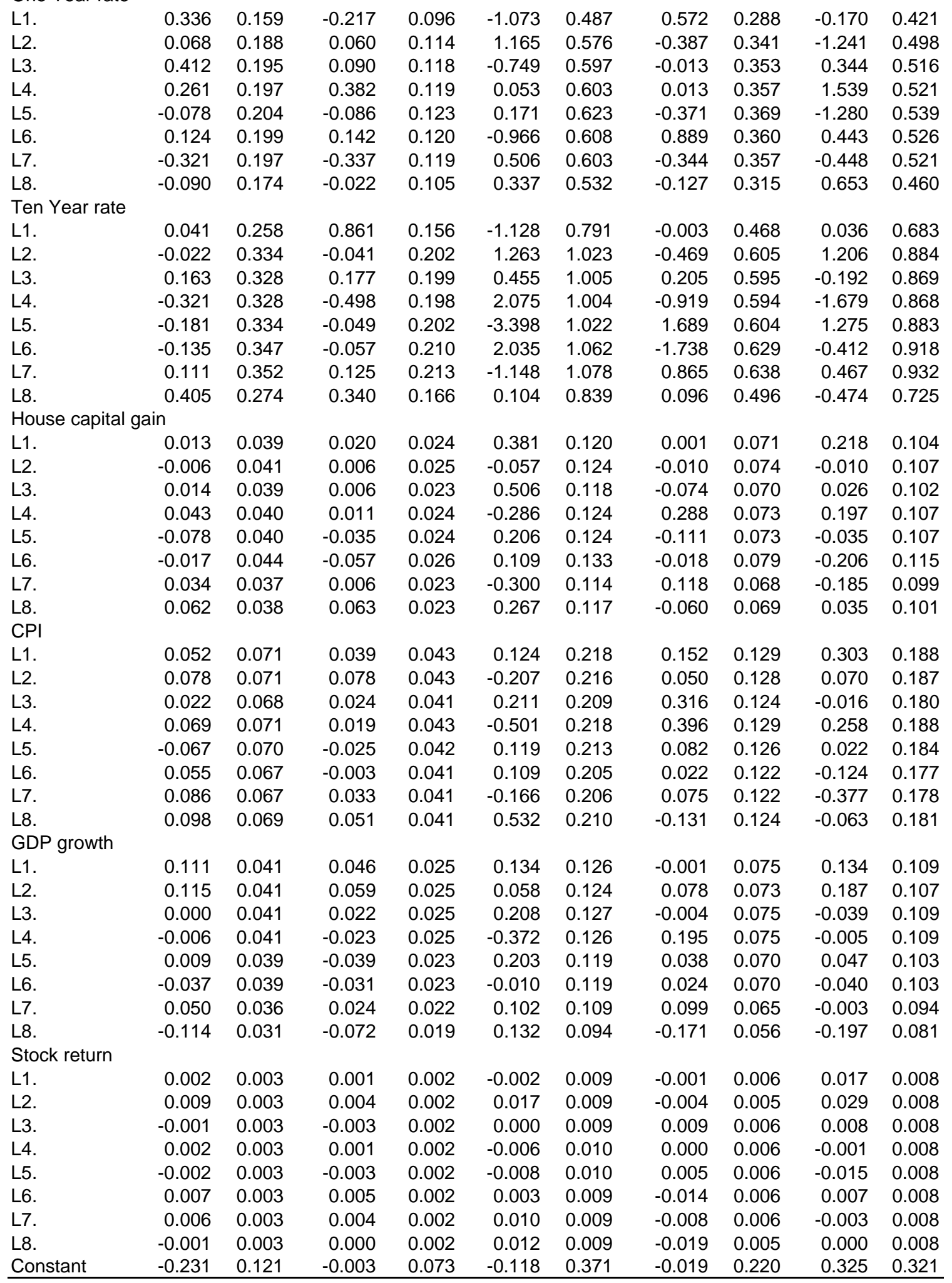




\section{RECENT WORKING PAPERS FROM THE \\ CENTER FOR RETIREMENT RESEARCH AT BOSTON COLLEGE}

The Impact of Aggregate Mortality Rise on Defined Benefit Pension Plans Irena Dushi, Leora Friedberg, and Anthony Webb, November 2006

Health Care Costs, Taxes, and the Retirement Decision: Conceptual Issues and Illustrative Simulations

Rudolph G. Penner and Richard W. Johnson, November 2006

Why Do Boomers Plan to Work So Long?

Gordon B.T. Mermin, Richard W. Johnson, and Dan Murphy, November 2006

Job Tenure and Pension Coverage

Alicia H. Munnell, Kelly Haverstick, and Geoffrey Sanzenbacher, October 2006

Has the Displacement of Older Workers Increased?

Alicia H. Munnell, Steven Sass, Mauricio Soto, and Natalia Zhivan, September 2006

No Place Like Home: Older Adults and their Housing

Timothy Smeeding, Barbara Boyle Torrey, Jonathan Fisher, David S. Johnson, and Joseph Marchand, August 2006

Effects of Public Policies on the Disposition of Lump-Sum Distributions: Rational and Behavioral Influences

William G. Gale and Michael Dworsky, August 2006

Pensions, Social Security, Wealth and Lifetime Earnings: Evidence from the Health and Retirement Study

William G. Gale and John W.R. Phillips, August 2006

Determinants and Consequences of Bargaining Power in Households

Leora Friedberg and Anthony Webb, June 2006

Earnings and Women's Retirement Security

Alicia H. Munnell and Natalia Zhivan, June 2006

Mortality Heterogeneity and the Distributional Consequences of Mandatory Annuitization

Guan Gong and Anthony Webb, June 2006

All working papers are available on the Center for Retirement Research website

(http://www.bc.edu/crr) and can be requested by e-mail (crr@bc.edu) or phone (617-552-1762). 